\title{
INTERNETINES RINKODAROS TENDENCIJOS IR EFEKTYVUMO VERTINIMO KRITERIJAI
}

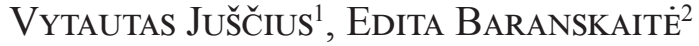 \\ Klaipèdos universitetas (Lietuva)
}

\begin{abstract}
ANOTACIJA
Sparti internetinès rinkodaros plètra neišvengiamai skatina investicijų šioje srityje augimą, tačiau ịmonèms gana sudètinga prognozuoti internetinès rinkodaros programų atsiperkamumą. Internetinės rinkodaros efektyvumo vertinimo kriterijai ir jo didinimo kryptys mokslinejje literatūroje nepakankamai ištirtos. Tyrimu siekta išanalizuoti internetinès rinkodaros krypčių efektyvumo vertinimo kriterijus ir jo didinimo galimybes. Straipsnyje, atlikus lyginamąją mokslinės literatūros analizę, atskleistos naujausios internetinės rinkodaros tendencijos, siejamos su antros kartos žiniatinkliu, lokalizacija ir daugiaekraniškumu. Pagrindinėmis internetinès rinkodaros kryptimis tampa paieškos sistemų optimizavimas ir rinkodara, elektroninio pašto ir invazinè rinkodara, sindikuotas turinys ir RSS, reitingų tinklalapiai, socialiniai tinklai, forumai, tinklalaidè, tinklaraščiai, valdikliai. Šių krypčių efektyvumas gali būti vertinamas finansiniais ir nefinansiniais rodikliais. Nefinansinių rodiklių pagrindas - vartotojų teikiamos pirmenybès. Finansiniais internetinès rinkodaros efektyvumo rodikliais tampa lankomumo, investicijų pelningumo (ROI) ir konversijos rodikliai.

PAGRINDINIAI ŽODŽIAI: internetinè rinkodara, efektyvumas, internetinés rinkodaros priemonés, internetinès rinkodaros efektyvumas.
\end{abstract}

JEL KLASIFIKACIJA: M310.

Ivadas

Interneto naudojimo galimybės nuolat plečiasi. Internetas yra ir technologija, ir komunikacijos kanalas, todèl internetinè rinkodara plètojama keletu skirtingų krypčių, kuriomis įmonės gali siekti rinkodaros tikslų.

Tyrimo problema. Mokslinèje literatūroje nemažai dèmesio skirta internetinès rinkodaros priemonių identifikavimui. Autoriai pristato visus internetinès rinkodaros instrumentus: SEO, SEM, rinkodarą už kompanijos tinklapio ribų ir sindikuotą rinkodarą, bendruomenių ir socialinių tinklų rinkodarą (Haligan et al., 2010; Lee et al., 2010; Parrott et al., 2011; Sharma, 2011; ir kt.), išskirti internetinès rinkodaros priemonių efektyvumo veiksniai (Gama, 2011; Rust, Ambler et al, 2004; Stewart, 2009; Nwokah, Ahiauzu, 2009). T. Gama išskyré finansines ir nefinansines matavimo kryptis (Gama, 2011), R. Rust, T, Ambler ir kiti - tris rinkodaros našumo matavimo kryptis (Rust, Ambler et al, 2004), D. W. Stewart analizavo 3 grąžos efektus:

1 Vytautas Juščius - Klaipėdos universiteto Ekonomikos katedros vedejjas. Moksliniai interesai: globalizacija, įmonių socialinè atsakomybè

El. paštas: ek.smf@ku.lt

Tel. +37046398677

2 Edita Baranskaitè - UAB „Basic Partner“ produkto specialistė. Moksliniai interesai: internetinė rinkodara El.paštas: edita@ekonomistai.eu

Tel. +37046398677 
trumpo, ilgo laikotarpių efektus ir realias galimybes (Stewart, 2009), N. G. Nwokah ir A. I. Ahiauzu (2009) analizavo korporatyvizmą, konkurencingumą, vartotojus ir egzogeninius veiksnius (Nwokah, Ahiauzu, 2009). Internetinès rinkodaros krypčių efektyvumo vertinimo kriterijai dar nèra iki galo ištirti. Neaišku, kiek kiekviena internetinès rinkodaros priemonè yra efektyvi ir naudinga, todèl įmonėms rengiant internetinès rinkodaros strategiją sudètinga atlikti prognozes ir racionaliai pasirinkti geriausią naudotinų rinkodaros krypčių rinkinị.

Tyrimo objektas - internetinès rinkodaros krypčių efektyvumas.

Tyrimo tikslas: išanalizuoti naujausias internetinès rinkodaros tendencijas, efektyvumo didinimo priemones ir krypčių efektyvumo vertinimo kriterijus.

Uždaviniai:

1. Išskirti naujausias internetinès rinkodaros tendencijas.

2. Identifikuoti internetinès rinkodaros efektyvumo didinimo priemones.

3. Nustatyti internetinès rinkodaros krypčių efektyvumo vertinimo kriterijus.

Tyrimo metodai: lyginamoji mokslinès literatūros analizè ir sintezè, sisteminimas, apibendrinimas.

\section{Naujausios internetinès rinkodaros tendencijos}

Tobulesnès informacinès technologijos suteikia naujų būdų perduoti, dalintis ir apdoroti informaciją. Internetas įmonėms sudarė galimybes išlikti konkurencingoms pateikiant klientams patogų, greitą ir pigesni būdą apsipirkti pigiau. Pasaulinis interneto tinklas leido daugybei įmonių transformuoti praeities problemas $i$ ateities galimybes, tapo veiksminga terpe pletojant santykius su klientais (Kim et al., 2009).

Makroekonominiu lygmeniu internetinè rinkodara lemia masinès rinkodaros svarbos mažėjimą. Tarpusavyje elektroniniu būdu susieti vartotojai turi galią reikalauti greitos prieigos prie individualizuoto, asmeniškai jiems pritaikyto turinio. Imonès privalo teikti individualizuotas patirtis bet kuriuo metu ir bet kurioje vietoje (Berman, Kesterson-Townes, 2012: 28). Informacinių technologijų ir interneto plètra spartina orientaciją ị segmentų rinkodarą. Masinė rinkodara keičiama ị rinkodara, kuri nukreipta ị konkretų vartotoją ar vartotojų grupę (Cova, White, 2010; Arens, 2006).

Viena svarbiausių pastarujų metų tendencijų - informacijos sklaidos šaltinių pasikeitimas (Sharma, 2011). Neišvengiama internetinès rinkodaros kryptis yra WEB 2.0, sukurianti natūralesnę vartotojo erdvę ir atverianti jam daugiau galimybių. D. L. Hoffman ir T. P. Novak pastebejo, kad vartotojai perima kontrolę kurdami antros kartos žianiatinkli - WEB 2.0. Keičiasi ir konkurencijos aplinka: iš vienkontekstės ji tampa daugiakontekste, iš ,vienas vienam“ ar „,vienas daugeliui“ - daugelis daugeliui rinkos struktūra (Hoffman, Novak, 2009: 32). Joje rinkodaros sprendimai turi rezonuoti su vartotojų poreikių kaita. Naujame kontekste išryškejja interaktyvumo svarba (Huang, 2003; Berman, Kesterson-Townes, 2012). Interaktyvumas tampa būtina sąlyga komunikacijos su vartotojais procese. Prisitaikymas prie kintančių vartotojų poreikių naudojant internetinès rinkodaros priemones atveria naujas galimybes didinti rinkodaros efektyvumą.

Apibendrintu pavidalu naujausios pagrindinès internetinès rinkodaros tendencijos pateiktos 1 paveiksle.

Informacinių technologijų plètra sudaro pagrindą tolesniems internetinès rinkodaros pokyčiams. Techninès priemonès leidžia vartotojui pasiekti internete esantị turinị ịvairiais prietaisais, būdais ir priemonèmis, kurios tiesiogiai susijusios su vartotojo suasmeninimo ir pasiūlos individualizavimo galimybèmis. 


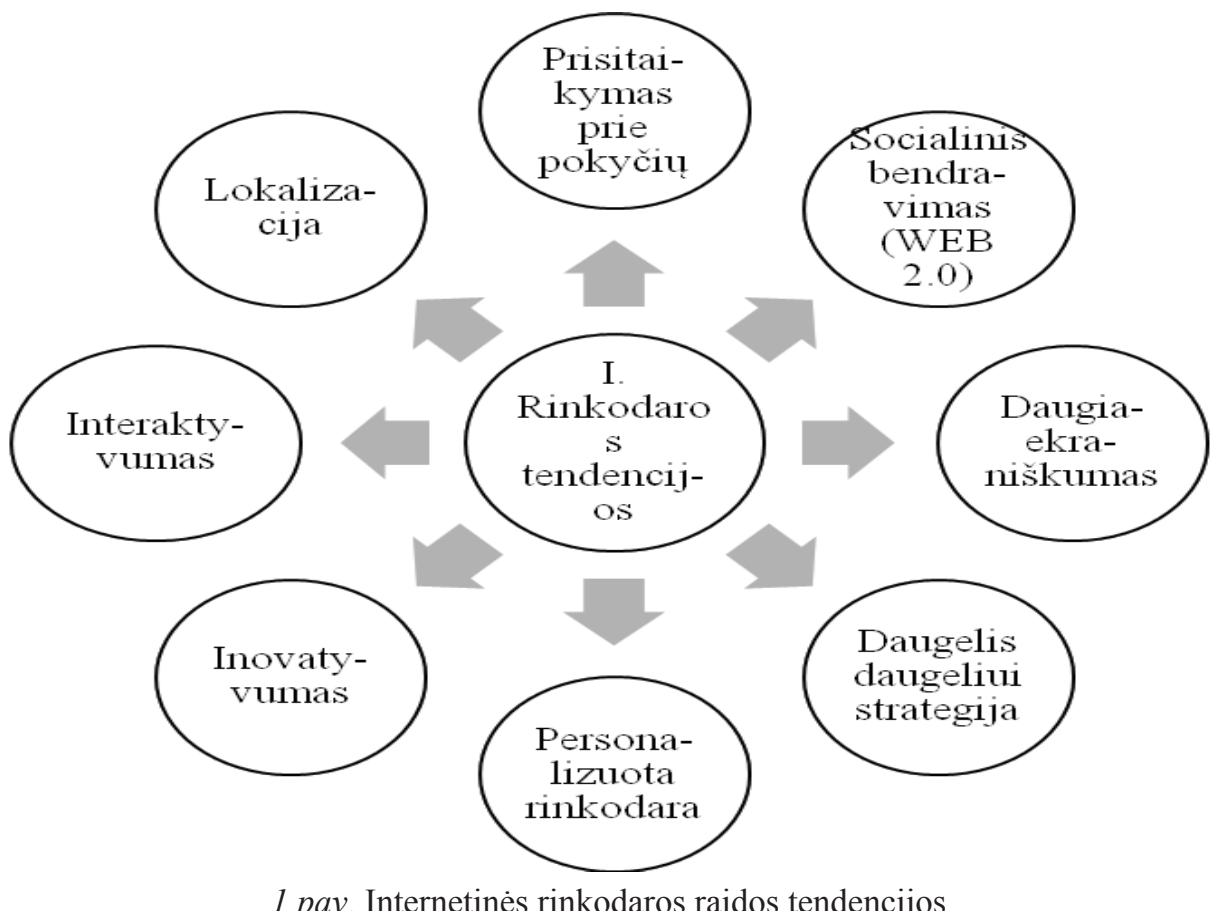

1 pav. Internetinès rinkodaros raidos tendencijos

\section{Internetinès rinkodaros efektyvumo didinimo priemonès}

Bendraujant su vartotoju ir siunčiant žinutę, būtina naudoti tinkamas interneto rinkodaros priemones. Mokslininkai akcentuoja, kad visos internetinės rinkodaros priemonès tarpusavyje susijusios, todèl turi būti nagrinėjamos kaip visuma (Kaklauskas, 2002; Palmer, 2000).

M. Kiškis, D. Talijūnas, J. Owyang, D. Chaffey identifikavo pagrindinius internetinès rinkodaros instrumentus:

1. Paieškos rinkodara. Paieškos sistemos (pvz., Google ir Yahoo) taiko rekomendavimo sistemas. Pasiūlomi labiausiai užklausos raktažodžius atitinkantys produktai ar paslaugos (Yannopoulos, 2011). Dauguma potencialių klientų taiko paieškos sistemas produkto paieškos fazėje (Owyang, 2008). Rezultatai, sugeneruoti atsižvelgiant ị vartotojo paieškos užklausą, gali būti skirstomi ị organinius ir mokamus paieškos rezultatus.

\section{a. Paieškos sistemų (SEO) optimizavimas}

Atsidurti daugelio paieškos sistemų sąrašo pradžioje suvokiama kaip tinklalapio validacija paieškos sistemų atžvilgiu (Thurow; 2006; Davis, 2006; Ledford, 2009). Jei tinklalapis atsiduria tarp geriausių paieškos sistemos rezultatų, reiškia, kad jis yra kokybiškas (Noaman, 2006).

\section{b. Paieškos sistemu (SEM) rinkodara}

Paieškos sistemos siūlo netradicinị reklamavimosi modelį, nes reklamos apmokestinamos, atsižvelgiant ị rezultatą. PPC (mokejjimas už paspaudimą) modelis paremtas tuo, kad mokama tik tada, kai klientas imasi kokių nors veiksmų. Šiuo atveju tai yra reklamos paspaudimas, kai vartotojas nukreipiamas ị įmonès tinklalapi (Nunan, Knox, 2011). Reklama paieškos sistemose gali vartotoją nuvilti. Prekès ženklas paieškos sistemose gali atsidurti netinkamoje vietoje (AGOF, 2008; Chen, Liu, Whinston, 2009; Drennan, Cornwell, 2004; Sohn ôc Jee, 2005; Telang et al., 2004). Reikia neužmiršti, kad SEO ir SEM skiriasi kaina, laiko sąnaudomis ir greičiu.

2. Rinkodara už kompanijos tinklalapio ribų ir sindikuota rinkodara naudojama pranešimams skleisti už tinklalapio ribų. Šis rinkinys plečia auditorijos dydị ir naudojamas tiesioginei rinkodarai. 
a) Elektroninio pašto rinkodara. Elektroninè reklaminè komunikacija (rinkodara e-paštu) nèra dominuojanti elektroninès rinkodaros forma. Teigiama, kad elektroninio pašto rinkodara sąnaudų požiūriu yra efektyviausias internetinès rinkodaros įrankis (Dehkordi, Rezvani et al, 2012).

b) Invaziné rinkodara. Iškylantys langai („Pop-Ups“ arba „Pop-Undres“), Trojos arkliai arba sekimo programos - visa tai negatyvios priemonès, skirtos pritraukti vartotojo dèmesį arba rinkti duomenis.

c) Sindikuotas turinys ir RSS (išsami puslapio santrauka). Sindikavimas ịtrauktas ị šią kategoriją, nes pastebima, kad rinkodara evoliucionuoja nuo „stūmimo“ prie „traukimo“ modelio. RSS leidžia vartotojui gauti papildomos informacijos pagal pateiktą užklausimą.

3. Bendruomenių ir socialinių tinklų rinkodara. Socialinių tinklų rinkodara skirta bendrauti su vartotoju interneto socialinėse erdvėse, kuriose vartotojai natūraliai leidžia savo laiką (Evans, McKee, 2010; Zarella, 2010; Owyang, 2008). Juose įmonès turi didžiulių galimybių pasinaudoti „iš lūpų ị lūpas“ rinkodaros privalumais (Trusov, Bucklin et al, 2009). Galima skirti šias socialinių tinklų erdves:

a) e-komercijos / reitingu tinklalapiai. Juose talpinamos redaktorių pastabos, vaizdo ịrašai, pavyzdžiai, vartotojų vertinimai ir nuomonès;

b) socialiniai tinklai, forumai, ,wiki“ bendradarbiavimas: visos šios formos naudojamos, siekiant sutelkti informaciją apie pasirinktą temą vienoje vietoje;

c) tinklalaide (angl. podcast) - tai ịvairios vaizdo ar garso įrašų transliacijos internete;

d) tinklaraščiai: tradicinèje žiniasklaidoje informacijos sklaida yra bekryptè, tačiau tinklaraščiai pateikè naują interaktyvumo paradigmą (Chiang, Hsien, 2011). Svarbiausia, kad vartotojų bendruomenès sukuria emocinè vertę. Vartotojai kuria bendruomeninius santykius, kurie siejami su prekès ženklais, produktais ir paslaugomis, su kuriomis bendruomenė kontaktuoja (Cova, White, 2010). B. Saxton pastebi, kad dauguma tinklaraščiu yra linkę veikti kaip informacijos filtrai su autoriaus komentaru (Saxton, 2008). A. Krishnamurthy pateikè keturias tinklaraščių tipologijas: asmeniniai, teminiai, individualūs ir bendruomeniniai (Krishnamurthy, 2002). W. Wood, R. Behling ir kiti pastebejjo, kad tinklaraščiais galima pasiekti daugybę reklamos kampanijos tikslų daug mažesnėmis sąnaudomis (Wood, Behling et al, 2006). T. Singh, L. Veron-Jackson ir kiti dèmesị atkreipe ị tinklaraščiu trūkumą - dèl staigios ịvairių medijos formų diversifikacijos poveikis individams gali sumažèti (Singh, Veron-Jackson et al, 2008). Tinklaraščiai suteikia ne tik naujų galimybių, bet ir iššūkių rinkodaros specialistams (Chiang, Hsien, 2011: 1246);

e) valdikliai (angl. widgets) - tai supaprastintos rinkmenos, kurias galima įdiegti ị tinklalapi, tinklaraštic, forumą ir ị profili socialiniuose tinkluose. „Flickr“, „MyBlogLog“, „Firefox communtity marketing campaign" - tai projektai, kurie sẻkmingai naudojasi šiuo instrumentu;

\section{f) Kitos galimybès}

Prie interneto rinkodaros priemonių galima priskirti santykių su klientais valdymo programas (CRM) (Jagdish, 2001). Tobulèjant informacinèms technologijoms atsiranda ir kitu naujos paieškos, informacijos ịvertinimo ir rūšiavimo paslaugų (Kiškis, 2009; Talijūnas, 2004; Owyang, 2004; Chaffey, 2009).

Internetinès rinkodaros priemonès gali būti apibūdinamos ịvairių savybių rinkiniu (žr. 1 lentelę).

Apibendrinant galima konstatuoti, kad visos internetinès rinkodaros priemonés turi tiek teigiamų, tiek neigiamų savybių. Šiomis priemonėmis pasiekiamas vartotojas, turintis skirtingų lūkesčių ir nevienodai išreikštą norą kontaktuoti su įmone. Tai reiškia, kad įmonè, noredama pasiekti savo rinkodaros tikslus, turètų pasirinkti ne vieną rinkodaros priemonę, o jų rinkinị pagal labiausiai ne tik jai, bet ir paskiriems vartotojams ar jų grupèms priimtinas savybes. 
1 lentelè. Internetinès rinkodaros priemonių savybės

\begin{tabular}{|c|c|c|}
\hline $\begin{array}{l}\text { Internetinès rinkodaros } \\
\text { priemonè }\end{array}$ & & Savybės \\
\hline \multirow{6}{*}{ Paieškos rinkodara } & \multirow{3}{*}{ Paieškos sistemų optimizacija (SEO) } & Nemokama \\
\hline & & Vartotojų pasitikèjimas \\
\hline & & Reikia daug laiko optimizuoti tinklalapi \\
\hline & \multirow{3}{*}{ Paieškos sistemų rinkodara (SEM) } & Greiti rezultatai \\
\hline & & Kainuoja \\
\hline & & Pirmos pozicijos sistemoje \\
\hline \multirow{8}{*}{$\begin{array}{l}\text { Rinkodara už tinklalapio } \\
\text { ribų ir sindikuota } \\
\text { rinkodara }\end{array}$} & \multirow{4}{*}{ El. pašto rinkodara } & Nemokama \\
\hline & & Asociacijos su brukalais \\
\hline & & $\begin{array}{l}\text { ES taikomas „Opt out“ teisinis modelis - } \\
\text { negalima siųsti laiško be gavèjo sutikimo }\end{array}$ \\
\hline & & $\begin{array}{l}\text { Antivirusiné programinè ịranga gali blokuoti } \\
\text { siuntejo serverị ateityje }\end{array}$ \\
\hline & \multirow{2}{*}{ Invazinè rinkodara } & Ikyru \\
\hline & & Rizikinga \\
\hline & \multirow[b]{2}{*}{ Sindikuotas turinys ir RSS } & Nemokama \\
\hline & & $\begin{array}{l}\text { Vartotojas kontroliuoja informaciją (,traukimo } \\
\text { modelis“") }\end{array}$ \\
\hline \multirow{11}{*}{$\begin{array}{l}\text { Socialinès medios } \\
\text { rinkodara }\end{array}$} & \multirow{4}{*}{ Reitingų tinklalapiai } & Vartotojai formuoja vieni kitų nuomonę \\
\hline & & Nemokama \\
\hline & & Efektyvu \\
\hline & & $\begin{array}{c}\text { İmonè nekontroliuoja informacijos, kuri } \\
\text { skleidžiama }\end{array}$ \\
\hline & \multirow{3}{*}{ Socialiniai tinklai, forumai } & Efektyvu \\
\hline & & Nemokama \\
\hline & & Vartotojai kontroliuoja turinị \\
\hline & Tinklalaidè & \\
\hline & \multirow{2}{*}{ Tinklaraščiai } & Formuojamas klientų lojalumas \\
\hline & & Neformalus bendravimas su klientu \\
\hline & Valdikliai & Neikyru \\
\hline
\end{tabular}

\section{Internetinès rinkodaros efektyvumo vertinimo kriterijai}

R. Rust, T. Ambler ir kiti išskyrè tris rinkodaros našumo matavimo kryptis. Pirmoji susijusi su rinkodaros veikos ilgo laikotarpio efektais. Antroji kryptis yra paskirų rinkodaros veiklų atskyrimas nuo kitų veiklų. Trečioji kryptis apima finansinių ir nefinansinių rodiklių derinimą. Rinkodaros investicijas nepakanka pagrịsti vien tik finansiniais metodais (Rust, Ambler et al, 2004: 1). Rinkodaros investicijų grąžąa atskleidžia ne tik finansiniai rodikliai. D. W. Stewart pastebejo, kad egzistuoja 3 rinkodaros investicijų grąžos efektai: trumpo laikotarpio, ilgo laikotarpio ir realios galimybès efektai (Stewart, 2009: 641) (žr. 2 pav.).

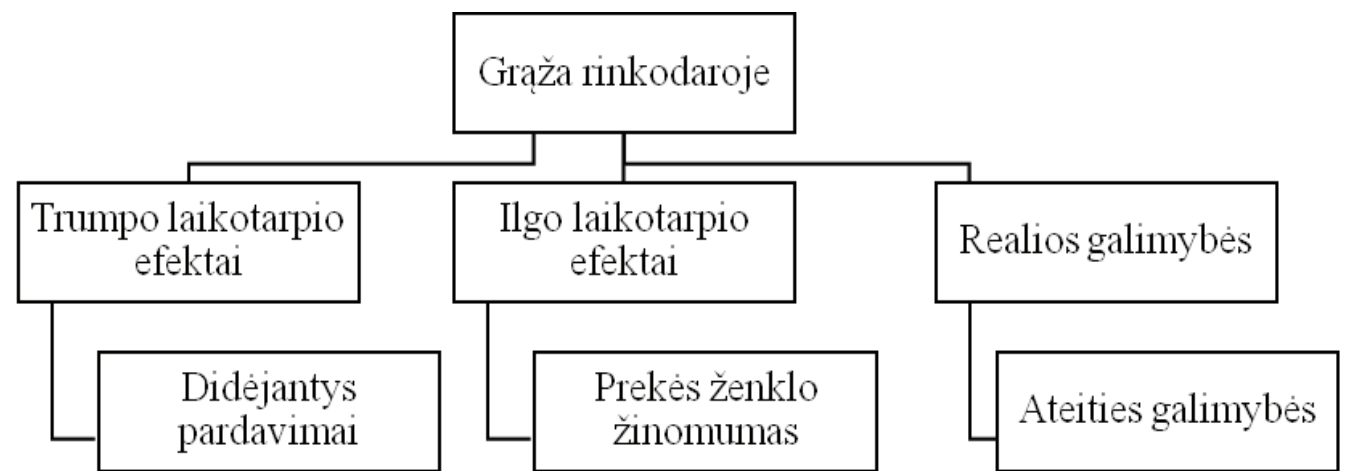

2 pav. Grąža rinkodaroje 
Rinkodaros efektyvumas visų pirma priklauso nuo to, kaip efektyviai rinkodaros strategija paverčiama rinkodaros veiksmais (Tuan, 2011: 131), o jo matavimai istoriškai nukreipti ị rezultatus: tiek finansinius, tiek nefinansinius (Gama, 2011).

Vertinant rinkodaros veiklos efektyvumą būtina ịvertinti pardavimo ir pelningumo rezultatus, rinkodaros programų efektyvumą, sąnaudas.

Pardavimo ir pelningumo rezultatų analizè. Pelningumo sąvoka vartojama dviem aspektais. Pirma, tai kapitalo, funkcionuojančio ịvairių vertybinių popierių pavidalu, duodamas pelnas ir antra, įmonès, kur veikia daugybė veiksnių, pelningumas (Rutkauskas, 2007: 49). Yra du pelno, gaunamo iš investicijų, tipai. Pirmasis pelno tipas - einamosios pajamos, gaunamos per visą turto laikymo periodą. Antrasis pelno tipas - pelnas, gaunamas pardavus tą turtą. Bendrasis investicijos pelnas apima ir einamąsias pajamas, ir kapitalo pelną, ir nuostoli. Pardavimo masto kontrolè remiasi pardavimo masto dinamikos analize ir mikroanalize.

N. Eechambadi pasiūlè finansinius rodiklius, kuriais galima ịvertinti rinkodaros veiklos efektyvumą (Eechambadi, 2002: 85) (žr. 2 lentelę).

2 lentelè. Rinkodaros metrikų analogija finansų metrikose

\begin{tabular}{|l|l|l|}
\hline \multicolumn{1}{|c|}{ Rinkodaros metrikos } & & \multicolumn{2}{c|}{ Finansinės metrikos } \\
\hline Atsako norma & & Pajamų didèjimas \\
\hline Išlaikymas atmintyje & & Padidèjęs pelningumas \\
\hline Kryžminio pardavimo norma & & Padidèjusios pajamos \\
\hline Vieno pardavimo sąnaudos & & Sumažejjusios įsigijimo išlaidos \\
\hline Vartotojų pasitenkinimas & & Sumažejjusios aptarnavimo sąnaudos \\
\hline
\end{tabular}

Rinkodaros programų efektyvumo kontrolè (nustatant, kurios rinkodaros išlaidos efektyvios, kurios neefektyvios). Atliekamas objektyvus ịvertinimas, ar vykdomos programos pasiekia nustatytus tikslus.

Kaštų analizè. İmonès kaštai, palyginus juos su konkurentų kaštais, yra svarbus strateginès padèties rodiklis. Kad įmonè sėkmingai konkuruotų, jos kaštai turi būti to paties lygio kaip ir varžovų. Norint kaštus palyginti su konkurentų kaštais, pasitelkiama veiklos kaštų grandinė, apimanti visas veiklos rūšis.

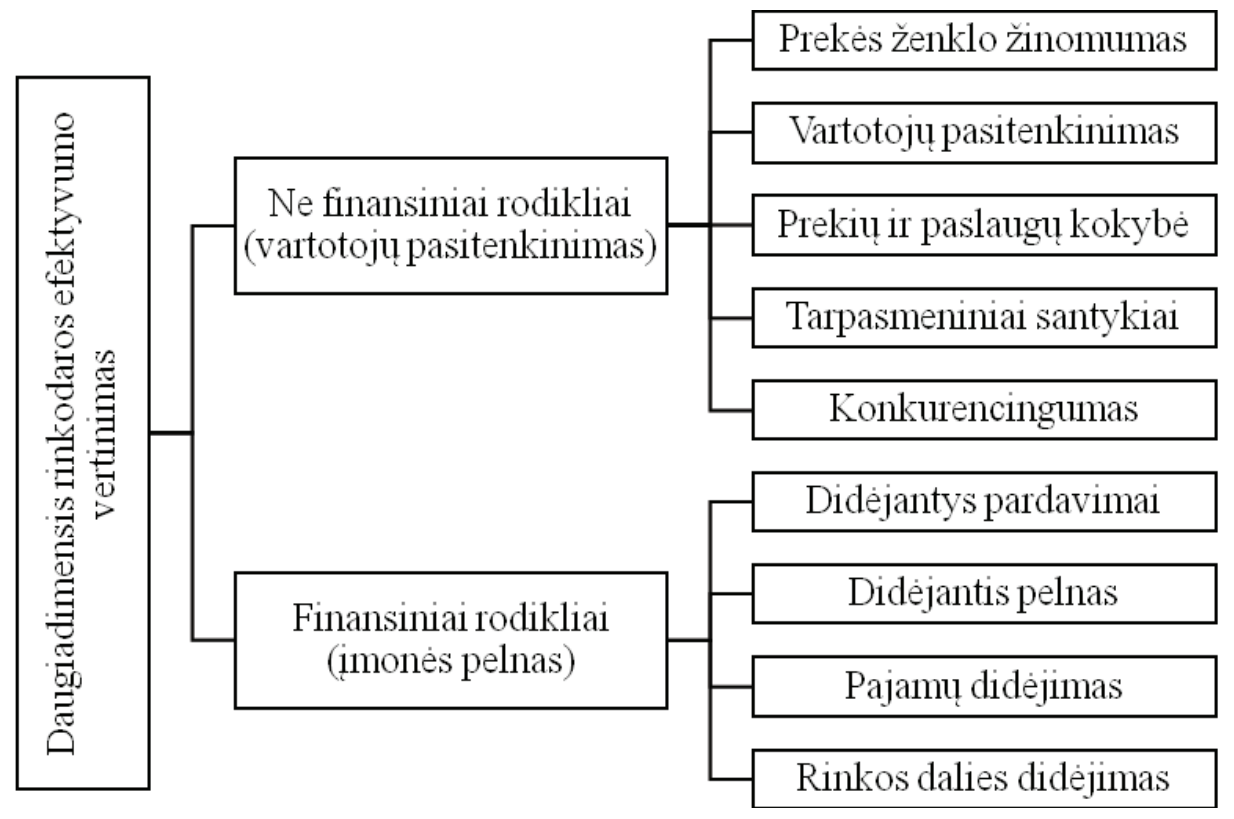

3 pav. Rinkodaros efektyvumo vertinimo rodikliai 


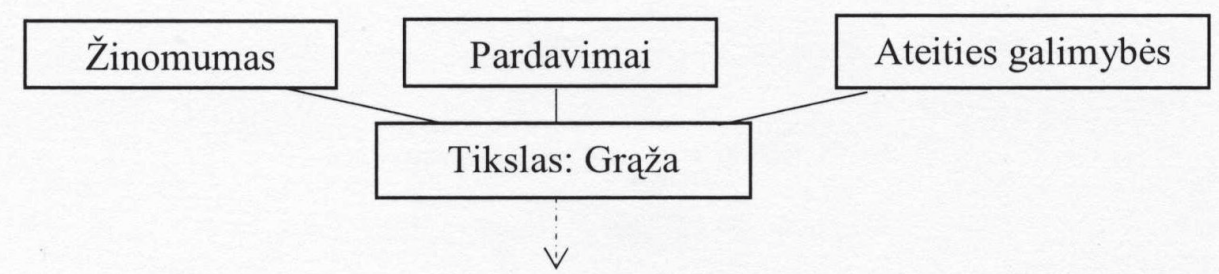

\begin{tabular}{|c|c|c|c|c|}
\hline \multicolumn{2}{|c|}{ Paieškos rinkodara } & \multicolumn{2}{c|}{ Rinkodara už tinklapio ribų } & \multirow{2}{*}{$\begin{array}{c}\text { Socialiniai } \\
\text { tinklai }\end{array}$} \\
\hline SEO & SEM & El. pašto rinkodara & Invazinè rinkodara & tink \\
\hline
\end{tabular}
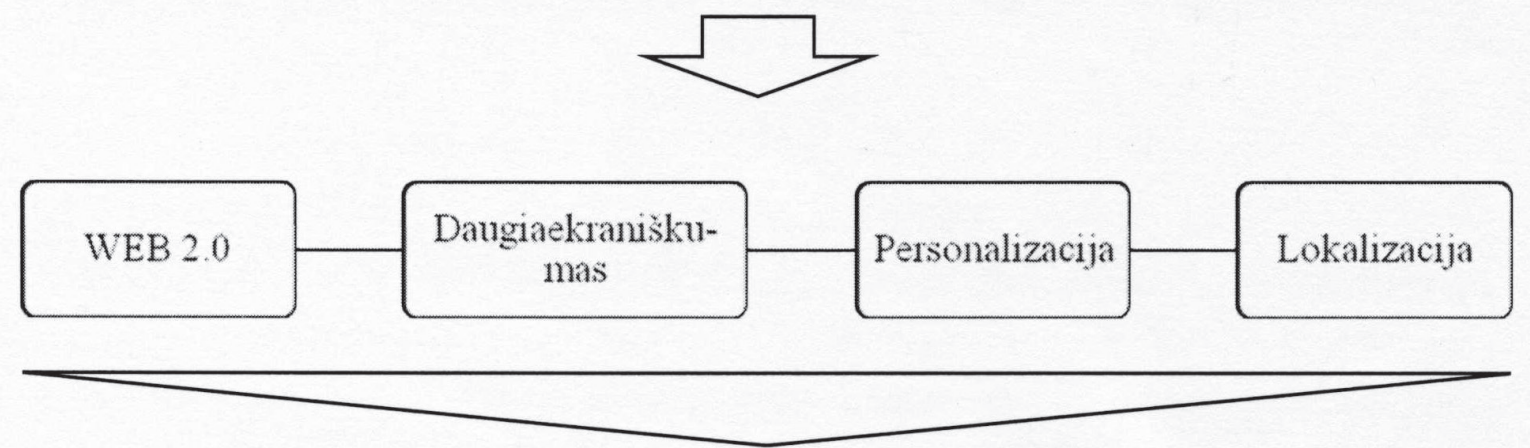

VARTOTOJO PIRMENYBE் PRODUKTUI

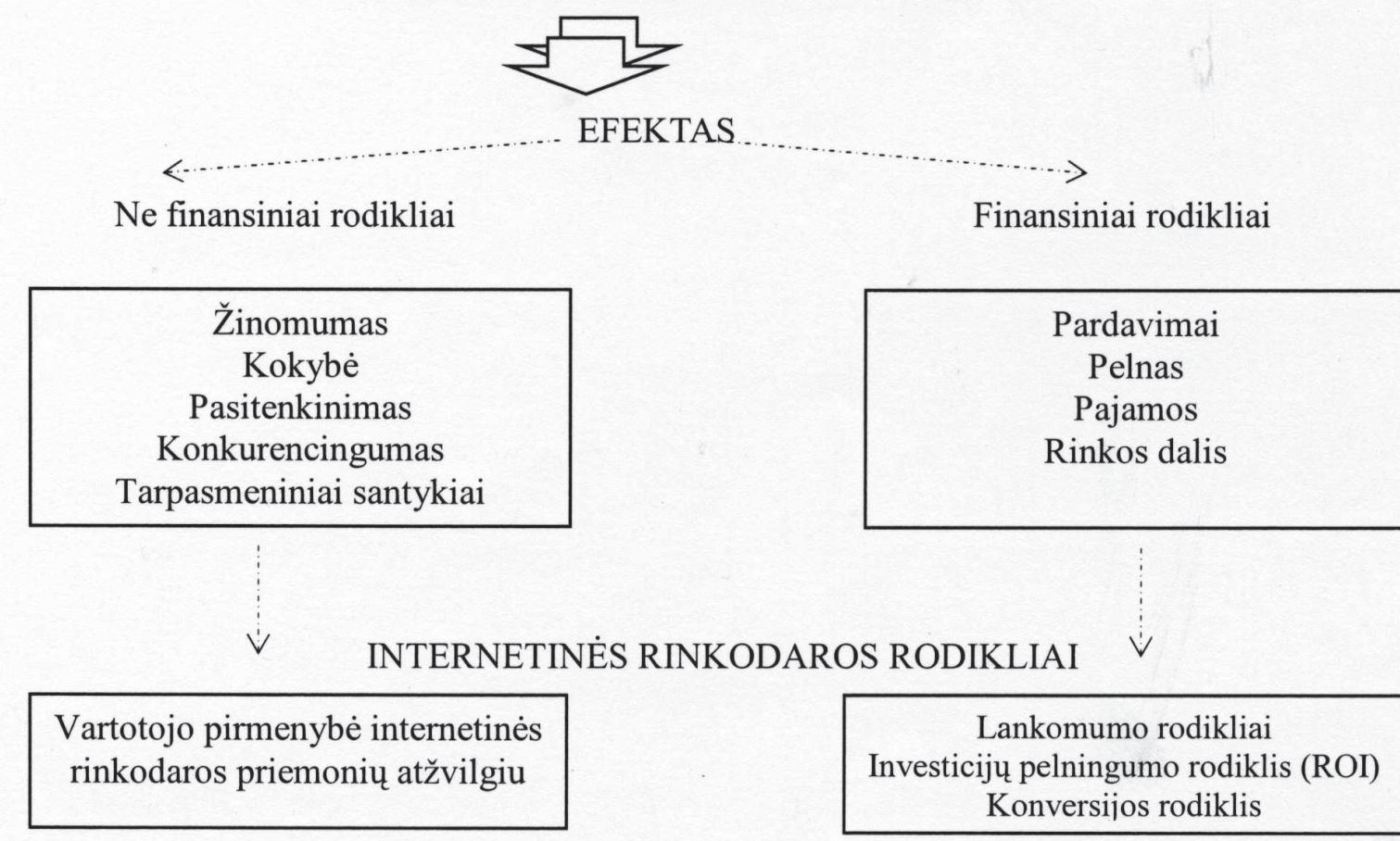

4 pav. Rinkodaros krypčių efektyvumo vertinimo modelis

Rinkodaros veiklos efektyvumui ịtakos turi ir nefinansiniai veiksniai: rinkodaros kultūra, paslaugų kultūra, paslaugų kokybè, tarpasmeniniai santykiai, santykių su klientais valdymas, organizacijos stabilumas, vidinè komunikacija, novatoriškumas ir kiti. 
Taigi rinkodaros efektyvumo vertinimas turi būti atliekamas atsižvelgiant ị finansinius ir nefinansinius kriterijus (žr. 3 pav.). Pateiktų rodiklių smulkesnès sudètinès dalys gali būti priskiriamos ilgo arba trumpo laikotarpio efektams.

Pateikti kriterijai apibrèžia rinkodaros efektyvumo dimensijas ir gali būti naudojami ịvairių įmonių rinkodaros veiklos vertinimui. Internetinès rinkodaros efektyvumo vertinimo specifiką apibrèžia vienas kriterijus - vartotojo prioritetai internetinès rinkodaros priemonių atžvilgiu. Remiantis bendraisiais rinkodaros efektyvumo vertinimo kriterijais, sudarytas internetinès rinkodaros efektyvumo didinimo krypčių modelis (4 pav.).

Šiame modelyje internetinès rinkodaros veikla grindžiama konkrečiais tikslais: žinomumu, pardavimų didinimu ir ateities galimybėmis, tai įgyvendinama specifinėmis priemonėmis. Savo ruožtu minètos priemonès gali būti nukreiptos skirtingomis kryptimis. Specifiniai priemonių ir krypčių deriniai sukuria (arba nesukuria) vartotojo suteikiamą pirmenybę konkrečiam prekès ženklui. Efektas įmonès veiklai matuojamas finansiniais ir nefinansiniais rodikliais, kurie skirstomi ị smulkesnius kriterijus. Rinkodaros krypties (priemonès ir priemonès kryptiškumo adaptacijos derinys) efektyvumas gali būti matuojamas dviem būdais: 1) tiriant vartotojo pirmenybes minètų derinių atžvilgiu; 2) analizuojant konkrečios įmonės tinklalapio lankomumo rodiklius, konversiją bei investicijų pelningumo rodiklius.

Išvados

Atlikus lyginamają mokslinės literatūros analizę galima išskirti naujausias internetinės rinkodaros tendencijas. Viena pagrindinių tendencijų - antros kartos žiniatinklio WEB 2.0 plètra, kuri iš esmès keičia vartotojų ir pardavejjų santykius. Naujasis žiniatinklis lemia tai, kad jo turinị formuoja ir iš dalies pardavejjo funkcijas perima pats vartotojas. Kita ryški tendencija - didejanti interneto prieigą turinčių prietaisų įvairovè. Vartotojai naudoja vis daugiau elektroninių prietaisų, kurie turi skirtingo dydžio ekranus (kompiuterius, išmaniuosius telefonus, planšetinius kompiuterius), kuriuose nori matyti vienodą turinį.

Pagrindinemis internetinès rinkodaros kryptimis tampa paieškos sistemų optimizavimas (SEO), paieškos sistemų rinkodara (SEM), elektroninio pašto rinkodara, invazinė rinkodara, sindikuotas turinys ir RSS, reitingų tinklalapiai, socialiniai tinklai, forumai, tinklalaidè, tinklaraščiai, valdikliai. Šiose kryptyse naudojamos priemonès skiriasi savo forma, savybèmis ir sąnaudomis. Vartotojai turi galimybę formuoti informaciją reitingų tinklalapiuose, forumuose, tinklaraščiuose, iš dalies socialiniuose tinkluose. Kitas priemones kontroliuoja pati įmonè.

Internetinès rinkodaros efektyvumo vertinimo specifiką - tam taikomas vienas kriterijus - vartotojo pirmenybė internetinès rinkodaros priemonių atžvilgiu. Sudarytas internetinès rinkodaros efektyvumo didinimo krypčių modelis sudaro pagrindą matuoti internetinès rinkodaros efektyvumą. Imonės veiklos efektas matuojamas finansiniais ir nefinansiniais rodikliais. Rinkodaros krypties efektyvumas gali būti matuojamas dviem būdais: tiriant vartotojo prioritetus minètų derinių atžvilgiu ir konkrečios ịmonès tinklalapio lankomumo rodiklius, konversiją bei investicijų pelningumo rodiklius.

\section{Literatūra}

AGOF. (2008). Internet Eacts 2008. Teil 1: Basisdaten Zur intemetnutzung. Prieiga internete: http://www.agof.de/studie.353.html

Berman, S. J., Kesterson-Townes, L. (2012). Connecting with the digital customer of the future. Strategy \& Leadership, Vol. 40, Issue 6, p. 29-35. Prieiga per EMERALD.

Chaffey, D., Chadwick, F., Mayer, R., Johnston, K. (2009). Internet marketing - strategy, implementation and practi$c e, 702$ p. Prieiga internete: http://books.google.lt/books?id=HcoRl2EZXiwC\&pg=PA179\&dq=5.\%09Chaffey,+ D.,+Chadwick,+F.+Richard+Mayer,Kevin+Johnston\&hl=lt\&sa=X\&ei=M_5ToaVN47EswbS6dT3Dw\&redir_ $\mathrm{esc}=\mathrm{y} \# \mathrm{v}=$ onepage $\& \mathrm{q} \& \mathrm{f}=$ false

Cova, B., White, T. (2010). Counter-brand and alter-brand communities: the impact of Web 2.0 on tribal marketing approaches. Journal of Marketing Management, Vol. 26, No. 3-4, March, p. 256-270. Prieiga per EBSCO duomenu bazę. 
Davis, H. (2006). Search Engine Optimization Building Traffic and Making Money with SEO. Prieiga internete: http:// www.expresspropertiesltd.co.uk/cms/UploadPdf/search.pdf

Dehkordi, G. J., Rezvani, S., Rahman, M. S., Nahid, F. F. N., Jouya. S. F. (2012). A Conceptual Study on E-marketing and Its Operation on Firm's Promotion and Understanding Customer's Response. International Journal of Business and Management, Vol. 7, No. 19. Prieiga internete: http://dx.doi.org/10.5539/ijbm.v7n19p114

E-strategija. (2010). Marketingo plano vykdymo kontrole. Prieiga internete: http://estrategija.lt/33Procesai/16Marketin gokontrole.htm

Evans, D., McKee, J. (2010). Social Media Marketing: The Next Generation of Business Engagement. Prieiga internete: http://books.google.lt/books?hl=en\&lr=\&id=ojcsI4fpfvEC\&oi=fnd\&pg=PT8\&dq=social+media + marketing \&ots $=$ oqN75o36A7\&sig $=$ YLHsn38ZmrudTjHNHu6ejf5rBSU\&redir_esc $=y \# v=$ onepage \&q $=$ social $\% 20$ media $\% 20$ marketing\&f=false

Gaižutis, A. (2004). Rinkodaros strategija ir valdymas, 53 p. Prieiga internete: http://www.google.com/url?sa=t\&rct= $\mathrm{j} \& \mathrm{q}=\&$ esrc $=\mathrm{s} \&$ source=web\&cd=2\&ved $=0 \mathrm{CDAQFjAB \& url}=\mathrm{http} \% 3 \mathrm{~A} \% 2 \mathrm{~F} \% 2 \mathrm{Fwww} \cdot \mathrm{marketing} .1 \mathrm{t} \% 2 \mathrm{Fget}$ file.php \%3Ffile\%3DL3d3dy9la29tZWRpZW5hLmx0L2RhdGEvbWFya2V0aW5nL20vbV9maWxlcy93ZmlsZXMvZmls ZTExOS5wZGY7MTEgU0tNYXJrX3N0cmF0LnBkZjs7\&ei=FISFT9zFDMia4ASVtr3pBA\&usg=AFQjCNFPK7 eWjQsg5eGGs9aUd8Nmoj2FGw\&sig2=5MgB3TPhW-Er0es8EU4zpQ

Gama, A. P. (2011). A renewed approach to services marketing Effectiveness, p. 3-17. Prieiga per EMERALD.

Gama, A. P. (2011). An expanded model of marketing performance. Prieiga per EMERALD.

Gok, H. (2010). The organizational roles of marketing and marketing managers, p. 291-309. Prieiga per EMERALD.

Gunawan, G. (2008). Performance measurement by internet retailers. Internet Research, Vol. 18, No. 4. Prieiga per EMERALD duomenų bazę.

Gunawan, G., Ellis-Chadwick, F., King, M. (2008). An empirical study of the uptake of performance measurement by internet retailers. Internet Research, Vol. 18, Nr. 4, p. 361-381. Prieiga per EBSCO duomenų bazę.

Haligan, B., Shah, D. (2010). Inbound Marketing. John Wiley and Sons Inc. Hoboken, New Jersey.

Hoffman, D. L., Novak, T. P. (2009). Flow Online: Lessons Learned and Future Prospects, p. 23-34. Prieiga internete: http://mail.tku.edu.tw/myday/teaching/992/SEC/S/992SEC_T3_Paper_20110513_Hoffman_Novak_2009_JIM.pdf

Yannopoulos, P. (2011). Impact of the Internet on Marketing Strategy Formulation. International Journal of Business and Social Science Vol. 2 No. 18; October 2011. Prieiga per EBSCO duomenų bazę.

Kaklauskas, A., Zavadskas, E. K. (2002). Internetine sprendimu parama. Monografija. Vilnius: Vilniaus Gedimino technikos universitetas.

Kim, J. H., Kim, M., Kandampully, J. (2011). The Impact of E-retail Buying Environment Characteristics on E-satisfaction and Purchase intent. International Journal of Service Science, Management, Engineering, and Technology, Vol. 2(3), p. 1-19, July - September. Prieiga per EBSCO duomenų bazę.

Kiškis, M. (2009). Socialiniai iššūkiai tiesioginei elektroninei rinkodarai. Prieiga internete: <http://internet.ktu.lt/lt/ mokslas/zurnalai/ekovad/14/1822-6515-2009-430.pdf

Ledford, J. (2009). SEO: Search Engine Optimization Bible. Prieiga internete: http://dl.acm.org/citation.cfm?id=1610315

Ledford, J. L. (2007). SEO: search engine optimization bible. Prieiga internete: http://books.google.lt/books?id=b5PT Scr05GcC\&dq=SEO\&hl=lt\&sa=X\&ei=uRPzTqbMEo-e-QbR6-jEAQ\&ved=0CFMQ6AEwBA

Noaman, A. (2006). Pick me! Pick me! ABA Bank Marketing, Vol. 38 (7), p. 34-38. Prieiga internete: http://www.slideshare.net/almthoma1984/seo-vs-ppc-7466200

Nunan, D., Knox, S. (2011). Can search engine advertising help access rare samples? International Journal of Market Research, Vol. 53, Issue 4, p. 523-540. Prieiga per EBSCO duomenų bazę.

Nwokah, N. G., Ahiauzu, A. I. (2009). Emotional intelligence and marketing effectiveness. Prieiga per EMERALD.

Owyang, J. (2010). Web Strategy. Prieiga internete: http://www.web-strategist.com

Palmer, A., McCole, P. (2000). The role of electronic commerce in creating virtual tourism destination marketing organizations. International Journal of Contemporary Hospitality Management, Vol. 12(3). Prieiga per EMERALD duomenų bazę.

Parrott, A., Roomi, C., Holliman, M. (2011). An analysis of marketing programmes adopted by regional small and medium-sized enterprises, p. 184-203. Prieiga per EMERALD.

Raila, M. (2011). Antros kartos žiniatinklio technologijų taikymo ir patogumo tyrimas glite grid telkinio darbo apskaitai ir analizei. Prieiga internete: http://dspace.vgtu.lt/bitstream/1/744/1/MRaila.pdf

Saxton, B. (2008). Information tools: Using blogs, RSS, and wikis as professional resources. Young Adult Library Services, Vol. 6, p. 27-29. Prieiga EMERALD duomenų bazę.

Sharma, A. (2011). Take-off of online marketing: casting the next generation strategies, p. 202. Prieiga per EMERALD duomenų bazę.

Singh, T., Veron-Jackson, L., Cullinane, J. (2008). Blogging: A new play in your marketing game plan. Business Horizons, Vol. 51, p. 281-292. Prieiga internete: http://doi.org/ccv 
Talijūnas, D. (2004). Reklama Internete: formos ir jų naudojimas; tendencijos. Reklamos ir marketingo idejos, Nr. 1. Prieiga internete: http://baitas.lzuu.lt/ mazylis/julram/19/82.pdf

Thurow, S. (2006). Debunking SEO myths. Prieiga internete: www.clickz.com/showPage.html?page=3587096

Trusov, M., Buckli, R. E., Pauwels, K. (2009). Effects of Word-of-Mouth Versus Traditional Marketing: Findings from an Internet Social Networking Site. Journal of Marketing, Vol. 73 (September), p. 90-102. Prieiga per EBSCO duomenų bazę.

Tuan, T. (2011). Marketing effectiveness and its precursors, p. 125-152. Prieiga per EMERALD.

Wood, W., Behling, R., Haugen, S. (2006). Blogs and business: Opportunities and headaches. Issues in Information Systems, Vol. 7(2), p. 312-316. Prieiga per EBSCO duomenų bazę.

Zittrain, J. (2008). The Future of the Internet--And How to Stop It, 342 p. Prieiga internete: http://books.google.lt/boo $\mathrm{ks}$ ?hl=en\&lr=\&id=DL3rx393NIQC\&oi=fnd\&pg=PR5\&dq=internet + marketing + future \&ots=uqIvu9JFoL\&sig=U2 Y4FY-pXhLcvpeZfa1L_3Y8U-s\&redir_esc $=\mathrm{y} \# \mathrm{v}=$ onepage \&q\&f=false

\title{
ONLINE MARKETING TRENDSAND EFFICIENCY EVAUATION C R I T E R I A
}

\author{
Vytautas Juščius, Edita Baranskaitė \\ Klaipèda University (Lithuania)
}

\section{Summary}

The article analyses a very important topic - directions for online marketing efficiency improvement. Online marketing is one of the fastest growing areas but the topic still lacks of scientific analyses. Companies face a marketing strategy efficiency evaluation problem. It is very difficult to calculate the payback of the chosen mix of online marketing tools. The aim of this article is to analyse the ways how to improve the online marketing efficiency. It was founded that the newest online marketing trends are WEB 2.0, localization and the multiscreen. The main online marketing tools are: Search Engines Optimization (SEO), Search Engines Marketing (SEM) email marketing, syndicated content, Pop Up, RSS, podcast, review websites, social media, discussion boards, blogs and widgets. The efficiency of those trends are identified by financial and non-financial criteria. Non-financial criteria is client priorities. Customer accepts online marketing tools differently, some tools are more appreciated than others. Financial criteria are user traffic on the website, the return on investment (ROI) and conversion rate. It is directly related to financial results as preference for the product is repressed by sales, income, profit and market share. Those variables are correlating with traffic on the website, conversion rate and ROI.

KEYWORDS: online marketing efficiency, online marketing directions, online marketing.

JEL CODES: M310. 